\title{
PENGETAHUAN DAN PERILAKU MENCUCI TANGAN PADA SISWA SMK SEBAGAI UPAYA PENCEGAHAN COVID-19
}

\author{
Siti Haryani ${ }^{1}$, Ana Puji Astuti ${ }^{2}$, Joyo Minardo ${ }^{3}$ \\ ${ }^{1-3}$ Prodi Diploma Tiga Keperawatan Universitas Ngudi Waluyo \\ haryanish01@gmail.com
}

\begin{abstract}
ABSTRAK
Masih rendahnya perilaku cuci tangan pakai sabun pada masyarakat dapat menimbulkan resiko penyebaran penyakit infeksi. Penyakit infeksi yang sedang berlangsung sekarang ini adalah COVID19 (Corona Virus Desases 19). Tujuan dilakukannya penelitian ini adalah untuk mengetahui serta memberikan gambaran mengenai pengetahuan dan perilaku mencuci tangan pada siswa SMK. Adapun manfaat dari penelitian ini secara teoritis adalah untuk memberikan pengetahuan kepada masyarakat mengenai pentingnya pencegahan penyakit melalui perilaku mencuci tangan. Penelitian ini menggunakan rancangan deskriptif observasional dengan pendekatan cross sectional, artinya pengumpulan data dilakukan terhadap responden untuk mengetahui hubungan antara pengetahuan dan perilaku mencuci tangan. Sasaran penelitian adalah siswa SMK Muhammadiyah Sumowono Kab. Semarang, Jawa Tengah Teknik pengambilan sampel dilakukan dengan metode random sampling. Jumlah sampel sebanyak 120 orang. Hasil penelitian menunjukkan bahwa $75 \%$ atau 90 siswa SMK Muhammadiyah Sumowono Kabupaten Semarang berpengetahuan baik, bahwa $85.8 \%$ atau 103 siswa SMK Muhammadiyah Sumowono Kabupaten Semarang berperilaku baik. Analisis bivariat menunjukkan hasil ada hubungan antara pengetahuan dan perilaku mencuci tangan dengan nilai signifikasi (p-value) sebesar 0.003, dimana p-value kurang dari $\alpha(0.05)$. Saran ditujukan untuk meningkatkan upaya pencegahan terhadap Covid-19, sebaiknya tetap dilakukan protokol kesehatan dengan $3 \mathrm{M}$ yaitu mencuci tangan mengguankan sabun, memakai masker dan menjaga jarak.
\end{abstract}

Kata kunci : Pengetahuan, Perilaku Mencuci Tangan, Covid-19

\begin{abstract}
The low behavior of washing hands with soap in the community can create a risk of spreading infectious diseases. The currently ongoing infectious disease is COVID-19 (Corona Virus Diseases 19). The purpose of this study was to determine and provide an overview of the knowledge and behavior of hand washing in vocational students. The theoretical benefit of this research was to provide knowledge to the public about the importance of preventing disease through hand washing.

This study used a descriptive observational design with a cross sectional approach, meaning that data collection was carried out on respondents to determine the relationship between knowledge and hand washing behavior. The research targets were students of Muhammadiyah Vocational School Sumowono Semarang Regency, Central Java. The sampling technique was carried out by random sampling method. The number of samples is 120 people. The results showed that $75 \%$ or 90 students of Muhammadiyah Vocational School Sumowono Semarang Regency had good knowledge, that $85.8 \%$ or 103 students of Muhammadiyah Vocational School Sumowono Semarang Regency had good behavior. The Bivariate analysis showed that there was a relationship between knowledge and hand washing behavior with a significance value ( $p$-value) of 0.003, where the p-value was less than $\alpha(0.05)$. Suggestions are aimed at increasing prevention efforts against Covid-19, it is better if the 3 $M$ health protocol is carried out, namely washing hands with soap, wearing masks and maintaining distance.
\end{abstract}

Keywords: Knowledge, Hand washing Behavior, Covid-19 


\section{Latar Belakang}

Pengetahuan adalah merupakan hasil dari tahu dan ini terjadi setelah orang melakukan penginderaan terhadap obyek tertentu. Penginderaan terhadap obyek terjadi melalui panca indera manusia, yakni: penglihatan, pendengaran, penciuman, rasa, dan raba. Sebagian besar pengetahuan manusia diperoleh melalui mata dan telinga (Notoatmodjo, 2012).

Tindakan adalah mekanisme dari suatu pengamatan yang muncul dari persepsi sehingga ada respon untuk mewujudkan suatu tindakan. Pengertian perilaku dapat dibatasi sebagai keadaan jiwa untuk berpendapat, berfikir, bersikap, dan lain sebagainya yang merupakan refleksi dari berbagai macam aspek, baik fisik maupun non fisik. Perilaku juga diartikan sebagai suatu reaksi psikis seseorang terhadap lingkungannya, reaksi yang dimaksud digolongkan menjadi bentuk pasif (tanpa tindakan nyata atau konkrit) dan dalam bentuk aktif (dengan tindakan konkrit). (Notoatmodjo, 2012)

CTPS (Cuci Tangan Pakai Sabun) merupakan usaha untuk menjaga kebersihan seluruh bagian tangan dengan media air dan sabun antiseptik sebagai penghilang kotoran. Melakukan CTPS merupakan salah satu usaha pencegahan penyakit yang mudah untuk dilakukan. Kebiasaan setiap anak dalam berperilaku mencuci tangan dengan sabun antiseptik agar terhindar dari berbagai macam penyakit sehingga dapat diterapkan dalam kegiatan seharihari. Kebiasaan setiap anak dalam berperilaku CTPS (Cuci Tangan Pakai Sabun) dengan benar perlu ditanamkan sejak dini. Keyakinan yang terbentuk dari perilaku CTPS agar terhindar dari berbagai macam penyakit dapat menjadi bentuk penerapan yang sering dijumpai setiap harinya. Demi memperoleh hasil yang maksimal, maka mencuci tangan hendaknya menggunakan air bersih yang mengalir dengan menggunakan sabun antiseptik, kemudian dikeringkan dengan handuk bersih atau menggunakan tisu (Kemenkes, 2010).

Perilaku CTPS menjadi penting mengingat fungsi dari tangan yang sering kontak dengan tubuh sendiri atau orang lain baik secara langsung maupun menggunakan media atau kontak tidak langsung. Bahaya muncul apabila kontak dilakukan dalam kondi tangan yang sedang kotor, hal ini dapat memicu penyebaran penyakit melalui pemindahkan bakteri, virus, dan parasit dari satu orang ke orang lain tanpa disadari.

Cuci tangan mengunakan sabun telah menjadi salah satu gerakan yang dicanangkan oleh pemerintah. Cuci tangan pakai sabun mampu untuk mengurangi angka diare sebanyak 45\%, tetapi pemakaian sabun untuk cuci tangan hanya mencapai sekitar 3\% dari seluruh masyarakat yang menggunakan sabun untuk cuci tangan. Masih rendahnya perilaku cuci tangan pakai sabun pada masyarakat dapat menimbulkan resiko penyebaran penyakit infeksi. Penyakit infeksi yang sedang berlangsung sekarang ini adalah COVID-19 (Corona Virus Desases 19).

Berdasarkan data yang diperoleh total jumlah pasien PDP (Pasien Dalam Pengawasan) di Jawa Tengah sebanyak 46 orang. Dari hasil cek laboratorium di Litbangkes, 37 orang di antaranya negatif corona , 2 orang positif corona dan 1 dinyatakan meninggal di RSUD Moewardi Surakarta (Pranowo, 2020). Sedangkan 1 PDP di rawat di RSUD Ambarawa (Mundjirin, 2020).

Tujuan dilakukannya penelitian ini adalah untuk mengetahui serta memberikan gambaran mengenai pengetahuan dan perilaku mencuci tangan pada siswa SMK. Adapun manfaat dari penelitian ini secara teoritis adalah untuk memberikan pengetahuan kepada masyarakat mengenai pentingnya pencegahan penyakit melalui perilaku mencuci tangan. 


\section{METODE PENELITIAN}

Metode Penelitian. Studi ini menggunakan rancangan deskriptif observasional dengan pendekatan cross sectional. Teknik pengambilan sampel dilakukan dengan metode random sampling. Jumlah sample sebanyak 120 (menggunakan rumus Slovin) . Metode pengambilan data menggunakan kuesioner. Variabel penelitian yang digunakan pada penelitian ini adalah Pengetahuan dan Perilaku mencuci tangan . Analisis data yang digunakan pada penelitian ini adalah sebagai berikut: Analisis univariat menggunakan distribusi frekuensi pada variabel pengetahuan dan perilaku. Analisis bivariat dilakukan dengan menggunakan uji Product Moment Pearson.

\section{HASIL DAN PEMBAHASAN}

\section{HASIL}

1. Karakteristik responden

a. Karakteristik responden berdasarkan usia

Karakteristik responden berdasarkan usia seperti pada tabel di bawah ini :

Tabel 1

Distribusi Responden berdasarkan usia

\begin{tabular}{ccc}
\hline Usia (tahun) & Jumlah & Persentase $(\%)$ \\
\hline 14 & 3 & 2.5 \\
15 & 25 & 21.7 \\
$\mathbf{1 6}$ & $\mathbf{4 6}$ & $\mathbf{3 8 . 3}$ \\
17 & 38 & 31.7 \\
18 & 4 & 3.3 \\
19 & 2 & 1.7 \\
20 & 1 & 0.8 \\
\hline Jumlah & $\mathbf{1 2 0}$ & $\mathbf{1 0 0}$ \\
\hline
\end{tabular}

Berdasarkan tabel 1 menunjukkan hasil bahwa $38.3 \%$ atau 46 siswa SMK Muhammadiyah Sumowono Kabupaten Semarang berusia 16 tahun .

b. Karakteristik responden berdasarkan jenis kelamin

Tabel 2

Distribusi Responden berdasarkan jenis kelamin

\begin{tabular}{ccc}
\hline Jenis Kelamin & Jumlah & Persentase (\%) \\
\hline Laki-laki & $\mathbf{8 0}$ & $\mathbf{6 6 . 6 7}$ \\
Perempuan & 40 & 33.33 \\
\hline & $\mathbf{1 2 0}$ & $\mathbf{1 0 0}$ \\
\hline
\end{tabular}

Berdasarkan tabel 2 menunjukkan hasil bahwa $66.67 \%$ atau 80 siswa SMK Muhammadiyah Sumowono Kabupaten Semarang berjenis kelamin lakilaki.

2. Sumber informasi

Tabel 3 Sumber informasi

\begin{tabular}{lcc}
\hline \multicolumn{1}{c}{ Sumber informasi } & Jumlah & Persentase (\%) \\
\hline Petugas Kesehatan & 19 & 15.8 \\
Media Elektronik & 4 & 3.3 \\
Guru & $\mathbf{5 9}$ & $\mathbf{4 9 . 2}$ \\
Keluarga & 34 & 28.3 \\
Lain-lain & 4 & 3.3 \\
\hline & $\mathbf{1 2 0}$ & $\mathbf{1 0 0}$ \\
\hline
\end{tabular}


Berdasarkan tabel 3 menunjukkan hasil bahwa $49.2 \%$ atau 59 siswa SMK Sumowono Kabupaten Semarang memperoleh informasi dari guru.

3. Pengetahuan

Tabel 4

Distribusi Responden berdasarkan Pengetahuan

\begin{tabular}{ccc}
\hline Pengetahuan & Jumlah & Persentase (\%) \\
\hline Kurang & 1 & 0.8 \\
Cukup & 29 & 24.2 \\
Baik & $\mathbf{9 0}$ & $\mathbf{7 5 . 0}$ \\
\hline Jumlah & 120 & 100 \\
\hline
\end{tabular}

Berdasarkan tabel 4 menunjukkan hasil bahwa 75\% atau 90 siswa SMK Muhammadiyah Sumowono Kabupaten Semarang berpengetahuan baik.

4. Perilaku Mencuci Tangan

Tabel 5 Distribusi Responden berdasarkan Perilaku Mencuci Tangan

\begin{tabular}{ccc}
\hline Pengetahuan & Jumlah & Persentase (\%) \\
\hline Cukup & 17 & 14.2 \\
Baik & $\mathbf{1 0 3}$ & $\mathbf{8 5 . 8}$ \\
\hline Jumlah & 120 & 100 \\
\hline
\end{tabular}

Berdasarkan tabel 5 menunjukkan hasil bahwa $85.8 \%$ atau 103 siswa SMK Muhammadiyah Sumowono Kabupaten Semarang berperilaku baik

5. Hubungan Pengetahuan dan Perilaku

Tabel 6 Hubungan Pengetahuan dan Perilaku

\begin{tabular}{cc}
\hline Hubungan & Signifikansi (p) \\
\hline $\begin{array}{c}\text { Pengetahuan dan } \\
\text { Perilaku }\end{array}$ & 0.003 \\
\hline
\end{tabular}

Berdasarkan tabel 6 bahwa antara pengetahuan dan perilaku terdapat hubungan dengan nilai $\mathrm{p}=0.03(\mathrm{p}<0.05)$.

\section{PEMBAHASAN}

\section{Usia}

Usia adalah lama waktu hidup atau ada (sejak dilahirkan atau diadakan). (KBBI, 2020). Berdasarkan data hasil penelitian bahwa usia responden sebagian besar adalah 16 tahun (38.3\%). Menurut Soetjiningsih (2016) bahwa usia 16 tahun masuk dalam tahapan periode perkembangan remaja dimana usia nya antara 12-18 tahun. Secara kemampuan kognitif usia remaja cukup baik dalam menerima informasi. Hal ini sejalan dengan penelitian Kartika, Widagdo, Anung (2016) dengan hasil analisis bivariat diketahui bahwa umur responden dengan perilaku cuci tangan pakai sabun yang baik, lebih besar pada kategori remaja $(54,8 \%)$ dibandingkan dengan kategori anakanak $(47,4 \%)$

\section{Jenis Kelamin}

Menurut WHO dalam Putra (2019) jenis kelamin adalah perbedaan biologis antara pria dan wanita. Perbedaan biologis tersebut dapat dilihat dari alat kelamin serta perbedaan genetik. Berdasarkan data hasil penelitian bahwa sebagian besar responden adalah lakilaki dengan jumlah 80 orang $(66.67 \%)$ 


\section{Sumber Informasi}

Menurut Raymond McLeod dalam Putra (2020) informasi adalah data yang sudah diolah menjadi bentuk baru yang memiliki makna bagi penerimanya dan bermanfaat untuk mengambil keputusan saat ini atau di masa depan. Orang yang memiliki sumber informasi yang lebih banyak akan memiliki pengetahuan yang lebih banyak pula (Notoatmodjo, 2010). Berdasarkan hasil penelitian bahwa sebagian besar informasi didapatkan dari guru sebesar $49.2 \%$. Menurut hasil penelitian didapatkan bahwa peran guru di sekolah dalam membiasakan praktek cuci tangan pakai sabun sebagian besar adalah baik $(60,7 \%)$. (Nugraheni , Widjanarko , Cahyo, 2010)

\section{Pengetahuan}

Pengetahuan atau knowledge adalah hasil penginderaan manusia atau hasil tahu seseorang terhadap suatu objek melalui pancaindra yang dimilikinya. Panca indra manusia guna penginderaan terhadap objek yakni penglihatan, pendengaran, penciuman, rasa dan perabaan. Pada waktu penginderaan untuk menghasilkan pengetahuan tersebut dipengaruhi oleh intensitas perhatiandan persepsi terhadap objek. Pengetahuan seseorang sebagian besar diperoleh melalui indra pendengaran dan indra penglihatan (Notoatmodjo, 2014).

Berdasarkan hasil penelitian menunjukkan hasil bahwa $75 \%$ atau 90 siswa SMK Muhammadiyah Sumowono Kabupaten Semarang berpengetahuan baik. Terdapat beberapa faktor yang mempengaruhi pengetahuan antara lain faktor pendidikan,pekerjaan, umur, lingkungan, social budaya. Pendidikan merupakan bimbingan yang diberikan seseorang terhadap perkembangan orang lain menuju impian atau cita-cita tertentu yang menentukan manusia untuk berbuat dan mengisi kehidupan agar tercapai keselamatan dan kebahagiaan. Pendidikan diperlukan untuk mendapatkan informasi berupa halhal yang menunjang kesehatan sehingga dapat meningkatkan kualitas hidup. Menurut YB Mantra yang dikutip oleh Notoatmodjo, pendidikan dapat mempengaruhi seseorang termasuk juga perilaku akan pola hidup terutama dalam memotivasi untuk sikap berpesan serta dalam pembangunan pada umumnya makin tinggi pendidikan seseorang maka semakin mudah menerima informasi.

\section{Perilaku}

Perilaku adalah suatu kegiatan atau aktivitas organisme yang bersangkutan, yang dapat diamati secara langsung maupun tidak langsung. Perilaku manusia adalah suatu aktivitas manusia itu sendiri (Notoadmodjo, 2010). Berdasarkan hasil penelitian didapatkan hasil bahwa $85.8 \%$ atau 103 siswa SMK Muhammadiyah Sumowono Kabupaten Semarang berperilaku baik. Perilaku manusia terbentuk karena adanya kebutuhan. Menurut Abraham Hildegard Maslow, manusia memiliki lima kebutuhan dasar, yakni kebutuhan fisologis, kebutuhan rasa aman dan nyaman, kebutuhan dicintai dan mencintai, kebutuhan harga diri dan kebutuhan aktualisasi diri. Perilaku dapat diberi batasan sebagai suatu tanggapan individu terhadap rangsangan yang berasal dari dalam maupun luar diri individu tersebut. Secara garis besar bentuk perilaku ada dua macam, yaitu pertama perilaku pasif (respons internal) yaitu perilaku yang sifatnya masih tertutup, terjadi dalam diri individu dan tidak dapat diamati secara langsung. Perilaku ini sebatas sikap belum ada tindakan yang nyata. Kedua, perilaku aktif (respons eksternal) yaitu perilaku yang sifatnya terbuka, perilaku aktif adalah perilaku yang dapat diamati langsung, berupa tindakan yang nyata.

\section{Hubungan Pengetahuan dan Perilaku Mencuci Tangan}

Berdasarkan hasil penelitian didapatkan hasil ada hubungan antara pengetahuan dan perilaku mencuci tangan dengan nilai signifikasi ( $p$-value) sebesar 0.003, dimana p-value 
kurang dari $\alpha(0.05)$. Dari hasil tersebut bahwa dapat disimpulkan bahwa pengetahuan yang baik akan menumbuhkan perilaku yang baik .

\section{SIMPULAN DAN SARAN}

\section{SIMPULAN}

Berdasarkan hasil penelitian didapatkan bahwa siswa SMK Muhammadiyah Sumowono Kabupaten Semarang mempunyai pengetahuan dan perilaku yang baik dengan ditunjukkan adanya hubungan antara pengetahuan dan perilaku mencuci tangan yang baik dengan $\mathrm{p}$ - value $0.003(<$ dari nilai $\alpha 0.05)$

\section{SARAN}

Untuk meningkatkan upaya pencegahan terhadap Covid-19, sebaiknya tetap dilakukan protokol kesehatan dengan $3 \mathrm{M}$ yaitu mencuci tangan mengguankan sabun, memakai masker dan menjaga jarak

\section{DAFTAR PUSTAKA}

Arif Putra. 2019. Pengertian Gender Menurut WHO, ternyata beda dengan Seks. https://www.sehatq.com/artikel/pengertian-gender-dan-perbedaannya-dengan-seks

DepKes RI. (2009). Panduan Penyelenggaraan Cuci tangan pakai sabun antiseptik Sedunia (HCTPS).Jakarta: Departemen Kesehatan RI

Halim dan Sudirham. 2018. Perilaku Cuci Tangan Di Kalangan Siswa-Siswi SMAK Santa Agnes Surabaya. https://e-journal.unair.ac.id/PROMKES/article/view/7122, Diunduh tanggal 13 Maret 2020.

Kamus Besar bahasa Indonesia. 2020. https://kbbi.web.id/

Kartika Mia, Widagdo Laksmono, Sugihantono Anung . 2016 . Faktor-Faktor yang Berhubungan dengan Perilaku Cuci Tangan Pakai Sabun pada Siswa Sekolah Dasar Negeri Sambiroto 01 Kota Semarang. JURNAL KESEHATAN MASYARAKAT (e-Journal) Volume 4, Nomor 5, Oktober 2016 (ISSN: 2356-3346) http://ejournals1.undip.ac.id/index.php/jkm

Lestari. 2019. Hubungan Pengetahuan Dan Sikap Terhadap Perilaku Cuci Tangan Pada Masyarakat Kelurahan Pegirian.Jurnal Promkes Vol. 7 No. 1 (2019)Volume 7 no. 1. https://e-journal.unair.ac.id/PROMKES/article/view/7122/7924

Notoatmodjo, S. (2012). Pendidikan dan perilaku kesehatan. Jakarta: PT. Rineka Cipta

Nugraheni Hermien, Widjanarko Bagoes, Cahyo Kusyogo. 2010. Praktek Cuci Tangan Pakai Sabun di Sekolah pada Siswa Sekolah Dasar di Kota Semarang. Jurnal Promosi Kesehatan Indonesia Vol. 5 / No. 2 / Agustus 2010 . https://ejournal.undip.ac.id/index.php/ipki/article/view/18694/13072

Putra. 2020. Pengertian Informasi: Fungsi, Konsep Dasar \& Jenis Jenis Informasi. https://salamadian.com/pengertian-informasi

Rikayanti, Kadek Herna. 2014. Hubungan Tingkat Pengetahuan Dengan Perilaku Mencuci Tangan Petugas Kesehatan Di Rumah Sakit Umum Daerah Badung Tahun 2013. Community Health, Volume 2, nomor. https://ojs.unud.ac.id/index.php/jch/article/view/7693/5783 
Soetjjiningsih. (2014). Tumbuh kembang anak. Jakarta:EGC. Jakarta

Tarwoto, Warwonah. 2004. Kebutuhan Dasar Manusia dan Proses Keperawatan Edisi ketiga. Jakarta :Salemba Medika.

Wikipwedia. 2020. Penyakit Korona Virus 2019. Diunduh pada tanggal 15 Maret 2020 Pukul 10.00.https://id.wikipedia.org/wiki/Penyakit_koronavirus_2019.

Wawan A. and Dewi M. (2011). Teori dan Pengukuran Pengetahuan, Sikap, dan Perilaku Manusia. Cetakan II.Yogyakarta: Nuha Medika.

WHO and Unicef. 2008. Progress on Drinking and Sanitation. Geneva:Unicef \& WHO.

WHO. 2009. Guidelines on Hand Hygiene in Healthcare. Geneva: WHO.

Trihadi,D (2009), Pengarut Terapi Kelompok terapeutik terhadap Kemampuan keluarga dalam memberikan stimulasi perkembangan dini usia kanak-kanak di Kelurahan Bubulak kota Bogor. (tesis). Jakarta: Fakultas Ilmu Keperawatan UI

Wong, D.L. (2004). Nursing care of infant and children. Texas: Mosby Year Book Inc

Yusuf, S. (2007). Psikologi perkembangan anak dan remaja. Bandung : PT Remaja 